https://doi.org/10.25100/iyc.v17i2.2192

INGENIERÍA DE ALIMENTOS

\title{
Aplicación de recubrimientos comestibles en rodajas de plátano verde sometidas a fritura por inmersión
}

FOOD ENGINEERING

\section{Application of edible coatings in green plantain slices subjected to deep-fat frying}

\author{
Darío F. Martínez*, Francisco J. Castellanos*§, Juan E. Bravo** \\ *Departamento de Ingeniería, Universidad de Caldas. Manizales, Colombia \\ ${ }^{* *}$ Facultad de Ciencias de la Ingeniería, Universidad Tecnológica Equinoccial. Quito, Ecuador \\ dario.2561322915@ucaldas.edu.co,sfrancisco.castellanos@ucaldas.edu.co,juan.bravo@ute.edu.ec
}

(Recibido: Abril 14 de 2015 - Aceptado: Junio 26 de 2015)

\section{Resumen}

Actualmente los pasabocas fritos tienen gran demanda por parte de los consumidores colombianos, sin embargo cuentan con alto contenido de aceite, que disminuye la vida útil del producto y su aceptabilidad sensorial. Una alternativa para reducir el contenido de aceite, puede ser el uso de hidrocoloides como recubrimientos comestibles. La aplicación de recubrimientos de goma Guar, CMC y goma Xanthan al 1,2\% fue adecuada para reducir el contenido de aceite en $43 \%, 31 \%$ y $23.34 \%$ respectivamente. Por otra parte, de acuerdo a la aplicación del diseño central compuesto rotable para el recubrimiento con goma Guar, las mejores condiciones de operación ocurrieron con una concentración de goma Guar de $1,4 \%$ y un tiempo de 90 segundos, cuando las rodajas de plátano se someten a unas condiciones de fritura por inmersión de $180^{\circ} \mathrm{C}$ y 3 minutos. Por lo tanto, los pasabocas de plátano recubiertos mantienen una buena calidad con bajo contenido de aceite, representando un producto más atractivo a los consumidores.

Palabras clave: Contenido de aceite, fritura por inmersión, pasabocas de plátano, recubrimientos comestibles.

\begin{abstract}
Currently fried snacks are in great demand by Colombian consumers, however they have a high oil content, which reduces the life of the product and its sensory acceptability. An alternative to reduce the oil content, can be the use of hydrocolloids as edible coatings. Applying coatings of Guar gum, CMC and Xanthan gum at $1.2 \%$ was adequate to reduce the oil content by $43 \%, 31 \%$ and $23.34 \%$ respectively. Moreover, according to the implementation of the rotable central composite design for the Guar gum coating, the best operating conditions occurred at a guar gum concentration of $1.4 \%$ and a time of 90 seconds, when the banana slices undergo deep-fat frying conditions of $180^{\circ}$ $\mathrm{C}$ and 3 minutes. Therefore, the coated plantain snack maintains a good quality with a low oil content, representing a more attractive product for consumers.
\end{abstract}

Keywords: Deep-fat frying, edible coatings, oil content, snacks plantain. 


\section{Introduction}

Plantains and other cooking bananas, are the staple foods produced in the tropics, are an important source of carbohydrates for the people of Africa, the Caribbean, Latin America, Asia and the Pacific. Plantain production worldwide in 2013 was $37^{\prime} 877,804$ tons, approximately $22.9 \%$ of the production comes from Latin America, standing out as major producers are Colombia, Peru and Ecuador (FAO, 2013). Much of the food market today consists of fried products of different materials, including roots, tubers, cereals, plantains, fish and chicken, these products are obtained by deep-fat frying, in the case of plantains one of the most common forms of consumption is chopped or sliced; deep-fat frying is widely used at the industrial, commercial and domestic scale for food preparation, as consumers prefer the taste, texture and appearance of fried products as well as the speed of the process compared to other cooking methods. This operation involves methods of drying and cooking through contact with hot oil, resulting in products with a high oil content (Bouchon, 2009). However, consumers currently demand products with low fat content and / or with a healthy fat mainly those fats with unsaturated fatty acids, since it is considered that the intake of lipids in excess is a factor for the presence of hypercholesterolemia and hypertension (Albert \& Mittal, 2002) and in some studies it has been associated with cardiovascular disease (Iqbal et al., 2008) and obesity (Orea, 2013). Therefore, fried foods have been directed to meet consumer demand, not only in the sensory aspects but also in the nutritional aspects. The challenge for the industry is to provide healthier fried foods with less fat and pleasant sensory characteristics for these products. Much of the research to reduce the oil content and improve the quality of fried products has been focused on the process, vacuum deep-fat frying is one of the most relevant (Bravo et al., 2011), others are focused on subjecting the food matrix to pre-treatments with methodologies such as microwave and convection drying, osmotic dehydration, blanching and the use of edible coatings, in this case, the use of hydrocolloids with thermal gelation capabilities or thickening properties have been widely studied as edible coatings. Coatings based on cellulose derivatives such as methylcellulose (MC), sodium carboxymethylcellulose (CMC) and hydroxypropylmethylcellulose (HPMC) have showed a good barrier to the absorption of oil during deep-fat frying (Albert and Mittal, 2002; Martelli et al ., 2008; Garcia et al, 2004).. Therefore, the use of hydrocolloids as edible coatings can be an alternative to meet the demands of current consumers, and thus be a promising route for obtaining Plantain snack low on calories, but investigations are still insufficient in relation to deep-fat frying while applying coatings in matrices such as plantain, since the surface of the food is important for the absorption of oil (Tavera-Quiroz et al., 2012). Therefore, the aim of this study was to determine the effect of the type of hydrocolloid, its concentration and the immersion time in solutions of hydrocolloids in terms of oil content and moisture content for plantain samples undergoing deep-fat frying at $180^{\circ} \mathrm{C}$ for 3 minutes.

\section{Methodology}

\subsection{Raw material}

For the study we worked with the Dominico Harton plantain variety in the green state according to Chavez et al. (2014) $\left({ }^{\circ}\right.$ Brix $\left.<7\right)$, it was purchased from a local market of Quito, Ecuador. Moisture was determined based on the AOAC (1997b) standard. For the analysis of soluble solids, a refractometer was used according to the AOAC (1998) standard; the acidity percentage was measured with respect to malic acid, being predominant in such fruit according to the AOAC (2005) standard. For the diameter, the middle part of the fruit was measured without exocarp with a caliper gauge $(160 \pm 0.05 \mathrm{~mm})$.

\subsection{Immersion process into the film forming solutions}

Sodium carboxymethyl cellulose, guar gum and Xanthan were used. Aqueous solutions were prepared for each hydrocolloid (CMC, GG and GX) 0.4 to $1.2 \%$ (weight / volume) and used as 
a plasticizer additive Propylene Glycol (50\% by weight of each hydrocolloid), each solution was heated to $60^{\circ} \mathrm{C}$ and kept under constant stirring for 5 minutes, then cooled to room temperature. For the apparent viscosities of the hydrocolloid solutions a Brookfield viscometer was used with an RTD temperature sensor at a temperature of $30^{\circ} \mathrm{C}$, using spindles \# 3 for the less viscous solutions and spindles \# 4 for more viscous, all measurements were made at 30 RPM.

The plantains were selected, washed, peeled and sliced ( $3 \mathrm{~mm}$ thick). An immersion was conducted in an antibrowning solution of sodium metabisulfite at $30 \mathrm{ppm}$ for 3 minutes. The plantain slices were coated through immersion in the hydrocolloids solutions for 15 and 30 seconds. A strainer was used to collect the coated slices and allowed them to drain for one minute, then surface drying was performed in a forced convection oven at $105^{\circ} \mathrm{C}$ for 4 minutes.

\subsection{Deep-fat frying process}

For the deep-fat frying process an electric fryer was used, with the Axis Anvil brand, model 2001.120 FFA, equipped with a temperature control system, worked at atmospheric pressure at a temperature of $180^{\circ} \mathrm{C}$ and a frying time of 3 minutes this temperature being a condition where the product absorbs more oil (Krokida et al., 2000) and the time was determined based on preliminary considerations of color and moisture. Industrial oil palm (Danolin Fri) was used in a ratio of 35 grams per liter of oil.

\subsubsection{Analysis of the fried product}

The moisture content was determined based on the AOAC (1997b) standard and the oil content was determined with hexane according to the AOAC (1997a) standard, the percent reduction of oil content was calculated according Martelli et al. (2008).

Texture: Considering that the aim of the study was to develop a coating that reduces fat absorption, the material showing greater reduction was selected for the studies of texture. The texture, defined as breaking strength of the plantain snacks, was performed by a texture analyzing equipment TAXT2 texture analyzer, with the brand SMS Stable Micro System. The determination was performed by 12 trials on each sample. The test involved applying a direct force over the sample, using a cylindrical probe of $1.25 \mathrm{~cm}$ in diameter at a descent rate of $4.0 \mathrm{~mm} / \mathrm{s}$. The snacks were kept on a base (hollow cylinder of 5.5 and $6.0 \mathrm{~cm}$ of internal and external diameter respectively), the sample was fractured and the peak value that represents the force was recorded (Lujan-Acosta \& Moreira, 1997).

\subsection{Statistical analysis}

An analysis of variance (ANOVA) was conducted to evaluate the significant differences between the levels of each factor (hydrocolloid type, concentration and time of immersion in the film forming solutions), using the Statgraphics Centurion software. When the data showed differences between them, the comparison of measurements was performed with the Tukey test at a significance level of 0.05 , the coating that showed a greater reduction of oil content was used for the realization of the response surface.

\subsection{Response Surface}

To evaluate the effect of applying the coating that showed higher values of oil reduction, a response surface methodology was used with a rotable central composite design, the effects of the independent variables were analyzed: Coating concentration $(\% \mathrm{w} / \mathrm{v})$ and immersion time ( $\mathrm{min})$. A high level and a low level for each factor were used as shown in Table 1 and 2.

\section{Results and discussion}

\subsection{Raw material}

The plantain selected for this research was of the Dominico hartón variety (AAB), which held values of moisture and total soluble solids of $65.0 \pm 2.10 \%$ and $3.60 \pm 0.10 \%$ ( ${ }^{\circ}$ Brix) respectively, while the titratable acidity and the pulp diameter remained at $0.33 \pm 0.12 \%$, and 3.04 $\pm 0.15 \mathrm{~cm}$ respectively. These data correspond to an evaluation of 20 samples of raw materials to ensure consistency, because the characteristics 
Table 1. Experimental range and factors levels

\begin{tabular}{ccccc}
\hline Command variables in the coating process & \multicolumn{2}{c}{ Encoded value } & \multicolumn{2}{c}{ Actual value } \\
& Minimum & Maximum & Minimum & Maximum \\
\hline Guar gum concentration (\% w/v) & -1 & 1 & 0.29 & 1.21 \\
Immersion time (s) & -1 & 1 & 17.45 & 77.55 \\
\hline
\end{tabular}

Table 2. Experimental design factors when using different immersion times and concentrations of Guar gum

\begin{tabular}{ccccc}
\hline Treatment & \multicolumn{2}{c}{ Encoded value } & \multicolumn{2}{c}{ Actual value } \\
\hline & $\mathrm{C}(\% \mathrm{p} / \mathrm{v})$ & $\mathrm{t}(\mathrm{s})$ & $\mathrm{C}(\% \mathrm{p} / \mathrm{v})$ & $\mathrm{t}(\mathrm{s})$ \\
1 & 0 & 0 & 0.75 & 47.50 \\
2 & 1 & 1 & 1.21 & 77.55 \\
3 & 0 & -1.4142 & 0.75 & 17.45 \\
4 & -1.4142 & 0 & 0.10 & 47.50 \\
5 & 1.4142 & 0 & 1.40 & 47.50 \\
6 & -1 & -1 & 0.29 & 17.45 \\
7 & 1 & -1 & 1.21 & 17.45 \\
8 & 0 & 1.4142 & 0.75 & 90.00 \\
9 & 0 & 0 & 0.75 & 47.50 \\
10 & 0 & 0 & 0.75 & 47.50 \\
11 & -1 & 1 & 0.29 & 77.55 \\
12 & 0 & 0 & 0.75 & 47.50 \\
13 & 0 & 0 & 0.75 & 47.50 \\
& Guar gum concentration (C) Time (t) & \\
\hline
\end{tabular}

of the raw material affect the quality of the final product.

\subsection{Immersion process into the film forming solutions}

Table 3 shows the apparent viscosity of the various solutions, according to the Tukey's test, statistically significant differences are found for each material and concentration. In this respect it is observed that the three materials produce viscous solutions at low concentrations and this increases directly with the concentration of each material. The Guar gum provides viscous solutions at different concentrations, this may be related to their waterbinding capacity, and is of great importance since many authors directly relate viscosity with the capacity for adhesiveness in edible coatings and in the case of additives mixtures of breaded and battered; It is also important in this research because the process was carried out by immersion, which requires high viscosity solutions, because if this is too low the coating will not adhere to the tissue of the plantain and will tend to fall, a fact that favored the synergy between the plantain and the coating material mainly with the guar gum (Akdeniz et al., 2006; Garcia et al, 2009; Altunakar et al., 2006). Moreover the Xanthan gum generates viscous solutions with $0.4 \%$, however when the concentration raises to $1.2 \%$ it did not develop viscosity like other materials, this may be related to poor hydration of the gum particles, leading to poor dispersion, which was evident through the clumping of the particles during the resulting mixture. Varela \& Fiszman (2011) in their comprehensive review, disclose that in the mixtures of chicken nuggets using (CMC, guar gum and xanthan gum) viscosity is remarkably increases with the addition of these materials, finding a relationship between the viscosity and the amount adhered to the substrate, however in this study the Xanthan gum had higher increases in viscosity than guar gum and CMC respectively; Akdeniz et al. (2006) found no significant differences in the adhesion capacity for Guar gum, xanthan and HPMC, however this was improved when combined with Guar and Xanthan gum increasing yield due to a high degree of synergy between these two gums. 
Table 3. Different apparent viscosities of coating suspensions

\begin{tabular}{ccc}
\hline Treatment & Concentration (\%) & $\begin{array}{c}\text { Apparent Viscosity } \\
(\mathrm{cps})\end{array}$ \\
\hline CMC & 0.4 & $238.9 \pm 1.2^{\mathrm{a}}$ \\
\multirow{2}{*}{ Xanthan Gum } & 1.2 & $7,840 \pm 40^{\mathrm{b}}$ \\
& 0.4 & $434.7 \pm 8.3^{\mathrm{c}}$ \\
Guar Gum & 1.2 & $2,820 \pm 13.2^{\mathrm{d}}$ \\
& 0.4 & $211.5 \pm 2.7^{\mathrm{e}}$ \\
& 1.2 & $15,266.7 \pm 152.8^{\mathrm{f}}$ \\
\hline
\end{tabular}

Measurements with different letters represent significant differences at the $5 \%$ level of significance $(P<0.05)$.

\subsection{Immersion deep-fat frying process for coated green plantain slices}

In Table 4 are presented the results of deep-fat frying coated green plantain slices depending on the moisture content, oil content and reduced oil content $(\%)$.
It is observed in Table 4 that for both the moisture content and for the oil content, there is no statistically significant influence related to the immersion time in the coating solution $(P$ $<0.05)$. These results agree with those reported by Baldwin et al. (2011), as these authors state that the immersion time is not important, however, if not enough, it will not form a good coverage; Therefore for the experiments to the response surface we worked with a wider time interval to evaluate its effect. With respect to the moisture content, statistically significant differences were found for each concentration and material (although between CMC and xanthan gum there was no difference) to a level of significance of $5 \%$. The relationship between the concentration of each coating and the moisture content was direct, a fact that is related to the ability to retain water due to the strong interaction of the resulting hydrogen bridges, between groups of molecules of

Table 4. Effect of different coatings in terms of moisture content and oil content in fried plantain snacks.

\begin{tabular}{|c|c|c|c|c|c|}
\hline Treatment & $\begin{array}{c}\text { Concentration } \\
(\%)\end{array}$ & $\begin{array}{l}\text { Immersion time } \\
\text { (s) }\end{array}$ & $\begin{array}{c}\text { Moisture content } \\
(\%)\end{array}$ & Oil content $(\%)$ & $\begin{array}{l}\text { Reduction in oil } \\
\text { content }(\%)\end{array}$ \\
\hline Control & -- & -- & $1.25 \pm 1.04$ & $30.07 \pm 1.60$ & -- \\
\hline \multirow[t]{4}{*}{$\mathrm{CMC}$} & 0.4 & 15 & $2.56 \pm 0.11^{\mathrm{a}}$ & $21.48 \pm 0.65^{\mathrm{a}}$ & $30.04 \pm 2.1^{\mathrm{a}}$ \\
\hline & & 30 & $2.50 \pm 0.33^{\mathrm{a}}$ & $24.01 \pm 1.16^{\mathrm{a}}$ & $21.79 \pm 3.79^{\mathrm{a}}$ \\
\hline & 1.2 & 15 & $2,58 \pm 0.08^{\mathrm{b}}$ & $21,18 \pm 0.97^{b}$ & $31.00 \pm 3.15^{b}$ \\
\hline & & 30 & $3,12 \pm 0.24^{b}$ & $22,55 \pm 0.60^{\mathrm{b}}$ & $26.54 \pm 1.94^{b}$ \\
\hline \multirow[t]{4}{*}{ Xanthan Gum } & 0.4 & 15 & $2.55 \pm 0.13^{\mathrm{a}}$ & $24.52 \pm 0.46^{c}$ & $20.12 \pm 1.49^{c}$ \\
\hline & & 30 & $2.22 \pm 0.11^{\mathrm{a}}$ & $24.61 \pm 0.99^{c}$ & $19.85 \pm 3.24^{c}$ \\
\hline & 1.2 & 15 & $2,93 \pm 0.55^{\mathrm{b}}$ & $23.88 \pm 0.42 \mathrm{~d}$ & $22.20 \pm 1.38^{\mathrm{d}}$ \\
\hline & & 30 & $2,07 \pm 0.06^{\mathrm{b}}$ & $23,53 \pm 0.60^{\mathrm{d}}$ & $23.34 \pm 1.96^{\mathrm{d}}$ \\
\hline \multirow[t]{4}{*}{ Guar Gum } & 0.4 & 15 & $3.30 \pm 0.26^{\mathrm{c}}$ & $22.91 \pm 0.54^{\mathrm{e}}$ & $25.37 \pm 1.75^{\mathrm{e}}$ \\
\hline & & 30 & $2.53 \pm 0.72^{\mathrm{c}}$ & $21.45 \pm 0.68^{\mathrm{e}}$ & $30.13 \pm 2.23^{\mathrm{e}}$ \\
\hline & 1.2 & 15 & $3,43 \pm 0.08^{\mathrm{d}}$ & $18.36 \pm 0.19^{\mathrm{f}}$ & $40.19 \pm 0.61^{\mathrm{f}}$ \\
\hline & & 30 & $3,61 \pm 0.51^{\mathrm{d}}$ & $17.50 \pm 0.34^{\mathrm{f}}$ & $43.01 \pm 1.09^{\mathrm{f}}$ \\
\hline
\end{tabular}

Measurements with different letters represent significant differences at the $5 \%$ level of significance $(P<0.05)$

hydrocolloids with the water. In terms of materials, it is evident that the higher moisture content corresponds to samples coated with guar gum (> $3 \%$ ) which is also related to its ability to bind and immobilize water, a product of its high viscosity. Akdeniz et al. (2006) found similar results in slices of fried carrot coated with different gums, the samples coated with HPMC, guar gum and xanthan gum showed a higher moisture content than the control samples, the higher moisture content from the samples was from the Guar and Xanthan gums; in the same way Sothornvit (2011) found that guar gum causes increased moisture retention, finding values of moisture content of $5.93 \%$ in banana snacks, with results similar to this study but significantly higher. However the moisture content is a variable to consider when edible coatings are used since, according to LujanAcosta \& Moreira (1997) the moisture content is a critical parameter for the product to develop the 
typical crispness attributes of a snack and because it ensures product stability (water activity).

As for the oil content, statistically significant differences were found for each concentration and material; a significance level of 5\%. A direct relationship between the concentration of each coating and the oil content is observed; the three materials also show a significant reductions in oil content, related to thermal gelation properties. Adding $1.2 \%$ of Guar gum reduces $43 \%$ of the absorbed oil content compared to the control samples, while the reduction for CMC and Xanthan gum was $31 \%$ and $23.34 \%$ respectively, this may be related to high viscosity resulting from the adhesion of the gum in the plantain, generating a good barrier against oil migration. Therefore guar gum was selected as a surface coating to assess response with broader range of time and evaluate its effect on the texture.

An inverse relationship between moisture and oil content was also found, using hydrocolloids favors the reduction of oil content in fried products, but there is moisture retention. Sothornvit (2011) found similar results but with smaller reductions, solutions of $1.5 \%$ guar gum produced a reduction of $25.22 \%$ and $17.22 \%$ for Xanthan gum solutions in terms of oil content in banana snack. Akdeniz et al. (2006) used as an HPMC additive, Xanthan and Guar gum in mixtures of breaded carrot, finding the best results with guar gum, however it concluded that the mixture of Guar gum and Xanthan improves the oil barrier properties. Some studies (Singthong \& Thongkaew, 2009; Garcia et al., 2002; Mai Tran et al., 2007;. Garmakhany et al, 2011) have shown that concentrations of 1 to $2 \%$ of different hydrocolloids help reduce oil absorption obtaining results similar to those of this investigation correlating the concentration with the effectiveness of the oil barrier.

\section{4 surface analysis}

Table 5 shows the results of the response variables relating to the quality attributes (moisture content, oil content and texture) in deep-fat frying of coated plantain snacks covered with Guar gum. Table 6 shows the fit of the model shown in the deep-fat frying process using edible coatings, the oil content is adjusted appropriately the resulting model has a coefficients of determination $\left(\mathrm{R}^{2}\right)$ of $87.8 \%$. According to the regression coefficients and figure 1a, shows the response surface of the percentage of oil content (\%) versus the concentration of guar gum and immersion time in the solution, it is observed that for the interval under consideration, the concentration of Guar gum and immersion time in the solution decreases the absorption of oil, significantly, as higher as the concentration of guar gum, the lower the amount of absorbed oil, being more sensitive to the effect of the concentration of time, but according to the information in Table 6 both linear effects, quadratic and interaction of both factors were significantly influential on the oil content. Indeed, the lowest oil absorption rates are obtained with higher concentrations of the hydrocolloid solution, in this case $1.4 \%$ Guar gum and 90 a second immersion. Furthermore, the interpretation of $\mathrm{R}^{2}(87.8 \%)$ indicates that the adjusted model explains $87.8 \%$ of the variability of the oil content, which means a good fit.

Table 5. Results of moisture content, oil content and texture of fried green plantain snacks coated with guar gum

\begin{tabular}{cccc}
\hline \multicolumn{4}{c}{ Response variables } \\
Treatment & $\begin{array}{c}\text { Oil content } \\
(\%)\end{array}$ & $\begin{array}{c}\text { Moisture } \\
\text { content (\%) }\end{array}$ & Texture (N) \\
\hline 1 & 23.5 & 2.9 & 13.7 \\
2 & 20.2 & 2.8 & 13.3 \\
3 & 25.1 & 4.9 & 13.9 \\
4 & 31.7 & 2.0 & 11.9 \\
5 & 17.8 & 3.1 & 12.1 \\
6 & 25.3 & 2.5 & 11.1 \\
7 & 20.5 & 2.7 & 11.3 \\
8 & 23.9 & 3.6 & 12.6 \\
9 & 24.3 & 3.3 & 12.5 \\
10 & 25.4 & 3.4 & 13.2 \\
11 & 26.7 & 2.4 & 11.1 \\
12 & 23.2 & 3.0 & 11.3 \\
13 & 24.85 & 3.23 & 13.42 \\
\hline
\end{tabular}



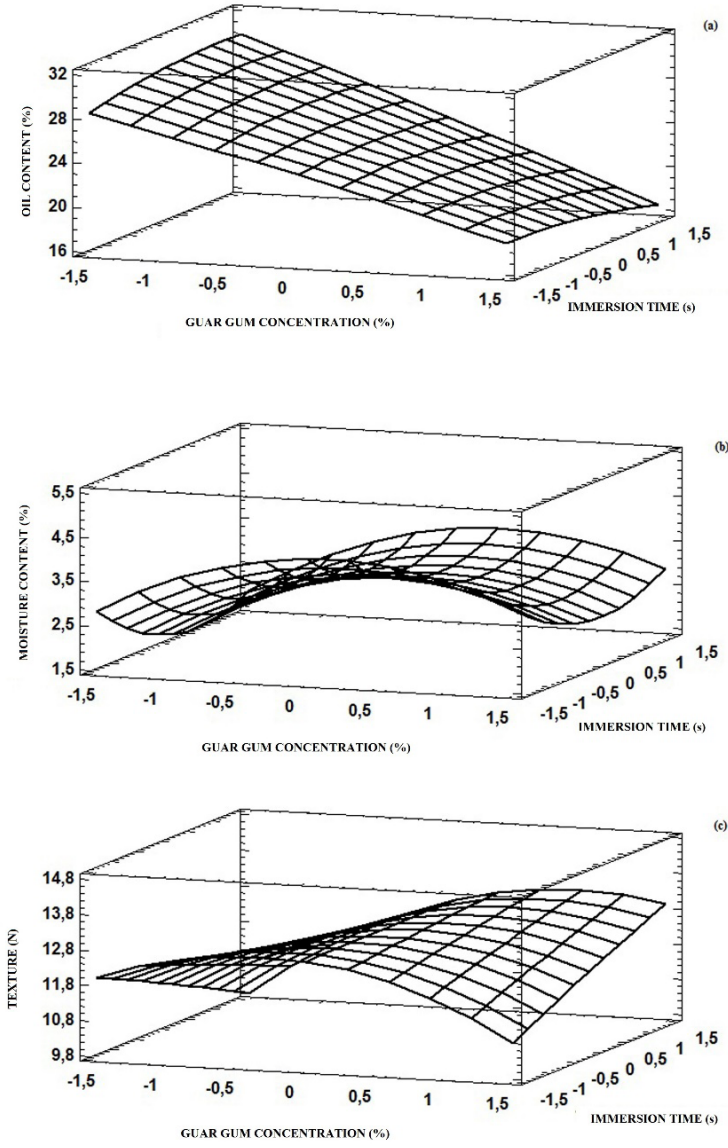

Figure 1. Response surface plot for (a) Oil content (b) Moisture content, and (c) Texture

Figure $1 \mathrm{~b}$ shows the response surface corresponding to moisture content in the plantain snack. The surface relating to the moisture content in the product corresponds to a saddle, as this increases from the center of the surface. Table 6 shows that only the linear effect of time and the quadratic effect of the concentration were significantly influential on the moisture content.
Moreover, the $\mathrm{R}^{2}$ indicates that the model explains only $66.3 \%$ of the moisture content. The answer shows no significant changes in concentration, however it slightly increases the immersion time.

Figure 1c shows the response surface for the analysis of texture; Table 6 shows that the linear effect of time and the quadratic effect of concentration and time are significantly influential on the texture, however the resulting model is not representative for texture as the coefficient of determination $\left(\mathrm{R}^{2}\right)$ is very low $(36.6 \%)$. The effect of time on the texture might be related to the fact that the longer the immersion there will be a greater adhesion of the coating material, creating a tendency to increase strength, this can be explained because the film offers protection against damage which could increase mechanical strength to break or fracture (Sothornvit, 2011). In samples with weak adhesion of Guar gum, in the process of deep-fat frying there is greater cell disruption and degradation of peptic substances in the structure of plantain, resulting in a weakening of the cell walls, while in samples coated for the required time, it not only serves as a barrier to oil absorption but gives protection during the process and therefore has a stronger break force (PunchaArnon et al., 2008). Similar results found TaveraQuiroz et al. (2012) on the application of coatings methylcellulose in potato snacks, concluding that such coatings with and without the addition of sorbitol does not affect the texture.

\section{Conclusions}

The use of edible coatings based guar gum, xanthan and $\mathrm{CMC}$ is feasible for fried products with lower oil content, highlighting Guar gum as more effective

Table 6. Analysis model setting

\begin{tabular}{|c|c|c|c|c|c|c|c|c|}
\hline \multicolumn{9}{|c|}{ Significance of each effect $(\mathrm{P}<0.05)$} \\
\hline & & Individual & & & & Quadratic & & Optimal \\
\hline & $\mathrm{R}^{2}$ & Cte & $\mathrm{C}$ & $\mathrm{t}$ & $\mathrm{Ct}$ & $\mathrm{C}^{2}$ & $\mathrm{t}^{2}$ & \\
\hline Oil & 87.8 & 24.2537 & -3.87879 & -0.062479 & -0.40515 & -0.114744 & -0.246074 & $\mathrm{C}=\alpha ; \mathrm{t}=\alpha$ \\
\hline Moisture & 66.3 & 3,157 & & -0.228604 & & -0.518816 & & $\begin{array}{c}C=-\alpha ; t= \\
0,45\end{array}$ \\
\hline Texture & 36.6 & 12,809 & & 0.0124842 & & -0.613885 & -0.018632 & $\mathrm{C}=-\alpha ; \mathrm{t}=\alpha$ \\
\hline \multicolumn{9}{|c|}{ Guar gum concentration $(\mathrm{C})$ Time $(\mathrm{t})$} \\
\hline
\end{tabular}


than other treatments in reducing oil absorption. The use of edible coatings generates moisture retention as it relates to the ability of immobilizing water which is a feature of hydrocolloids. The response surface methodology established that for the studied process low oil content $(17.4 \%)$ can be achieved in the area near time $=90$ seconds and Guar gum in a concentration $=1.4 \%$.

Emerging technologies based on edible coatings combined with a process of deep-fat frying, maintain the quality and addressed fried products as a healthier product, because of its lower oil content, as a new alternative for the needs and tastes of consumers.

\section{References}

Akdeniz, N., Sahin, S. \& Sumnu, G. (2006). Functionality of batters containing different gums for deep-fat frying of carrot slices. Journal of Food Engineering 75 (4), 522-526.

Albert, S. \& Mittal, G. S. (2002). Comparative evaluation of edible coatings to reduce fat uptake in a deep-fried cereal product. Food Research International 35 (5), 445-458.

Altunakar, B., Sahin, S. \& Sumnu, G. (2006). Effects of hydrocolloids on apparent viscosity of batters and quality of chicken nuggets. Chemical Engineering Communications 193 (6), 675-682.

AOAC. (1997a). Official Method of crude fat or ether extract determination (Method 920.39) The Association of Official Analytical Chemists International, Washington, DC, USA.

AOAC. (1997b). Official Methods of moisture analysis (Method 934.01) The Association of Official Analytical Chemists International, Washington, DC, USA.

AOAC. (1998). Official Methods of Solids Total (Method 932.12) The Association of Official Analytical Chemists International, Washington, DC, USA.

AOAC. (2005). Official Method of titratable acidity (Method 942.15) The Association of
Official Analytical Chemists International, Washington, DC, USA.

Baldwin, E. A., Hagenmaier, R. \& Bai, J. (2011) Edible coatings and films to improve food quality. Florida: CRC Press, Inc

Bouchon, P. (2009). Chapter 5 Understanding Oil Absorption During Deep-Fat Frying. In: Steve, L. T. (ed.) Advances in Food and Nutrition Research. Academic Press.

Bravo, J., Sanjuán, N., Clemente, G. \& Mulet, A. (2011). Pressure Effect on Deep Fat Frying of Apple Chips. Drying Technology 29 (4), 472-477.

Chávez, A., Castellanos, F. \& Martínez, L. (2014). Evaluación del proceso de maduración de variedades de plátano durante el almacenamiento. II Congreso Internacional de Investigación e Innovación en Ingeniería, Ciencia y Tecnología de Alimentos (IICTA), Medellín, Colombia 67 (2), 445-447.

FAO. 2013. Producción de plátano en el 2013 [Online]. Available: http://faostat.fao.org/ site/339/default.aspx [Accessed marzo 2014].

García, M., Ferrero, C., Campana, A., Bértola, N., Martino, M. \& Zaritzky, N. (2004). Methylcellulose coatings applied to reduce oil uptake in fried products. Food science and technology international 10 (5), 339-346.

García, M., Pinotti, A., Martino, M. \& Zaritzky, N. (2009). Characterization of Starch and Composite Edible Films and Coatings. In: Huber, K. C. \& Embuscado, M. E. (eds.) Edible Films and Coatings for Food Applications. Springer New York, USA.

García, M. A., Ferrero, C., Bértola, N., Martino, M. \& Zaritzky, N. (2002). Edible coatings from cellulose derivatives to reduce oil uptake in fried products. Innovative Food Science \& Emerging Technologies 3 (4), 391-397.

Garmakhany, A. D., Aghajani, N. \& Kashiri, M. (2011). Use of hydrocolloids as edible covers 
to produce low fat french fries. Latin American applied research 41, 211-216.

Hsia, H., Smith, D. \& Steffe, J. (1992). Rheological Properties and Adhesion Characteristics of FlourBased Batters for Chicken Nuggets as affected by Three Hydrocolloids. Journal of Food Science 57 (1), 16-18.

Krokida, M., Oreopoulou, V. \& Maroulis, Z. (2000). Water loss and oil uptake as a function of frying time. Journal of Engineering, 44(1), 39-46.

Iqbal, R., Anand, S., Ounpuu, S., Islam, S., Zhang, X. \& Rangarajan, S. (2008). Dietary patterns and the risk of acute myocardial infarction in 52 countries: results of the INTERHEART study. Circulation 118 (19), 1929-1966.

Lujan-Acosta, J. \& Moreira, R. G. (1997). Reduction of Oil in Tortilla Chips using Impingement Drying. LWT - Food Science and Technology 30 (8), 834-840.

Mai Tran, T. T., Chen, X. D. \& Southern, C. (2007). Reducing oil content of fried potato crisps considerably using a 'sweet' pre-treatment technique. Journal of Food Engineering 80 (2), 719-726.

Martelli, M. R., Carvalho, R. A., Sobral, P. J. A. \& Santos, J. S. (2008). Reduction of oil uptake in deep fat fried chicken nuggets using edible coatings based on cassava starch and methylcellulose. Italian journal of food science 20 (1), 111-117.

Orea, S., Martinez-Gonzalez, M. A., Gea, A., Flores-Gomez, E., Basterra-Gortari, F. J., \& BesRastrollo, M. (2013). Consumption of fried foods and risk of metabolic syndrome: The SUN cohort study. Clinical Nutrition.

Puncha-arnon, S., Pathipanawat, W., Puttanlek, C., Rungsardthong, V. \& Uttapap, D. (2008). Effects of relative granule size and gelatinization temperature on paste and gel properties of starch blends. Food Research International 41 (5), 552-561.

Singthong, J. \& Thongkaew, C. (2009). Using hydrocolloids to decrease oil absorption in banana chips. LWT - Food Science and Technology 42 (7), 1199-1203.

Sothornvit, R. (2011). Edible coating and postfrying centrifuge step effect on quality of vacuumfried banana chips. Journal of Food Engineering 107 (3-4), 319-325.

Tavera-Quiroz, M. J., Urriza, M., Pinotti, A. \& Bertola, N. (2012). Plasticized methylcellulose coating for reducing oil uptake in potato chips. Journal of the Science of Food and Agriculture 92 (7), 1346-1353.

Varela, P., \& Fiszman, S. (2011). Hydrocolloids in fried foods. A review. Food Hydrocolloids 25 (8), 1801-1812.

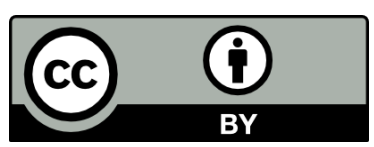

Revista Ingeniería y Competitividad por Universidad del Valle se encuentra bajo una licencia Creative Commons Reconocimiento - Debe reconocer adecuadamente la autoría, proporcionar un enlace a la licencia e indicar si se han realizado cambios. Puede hacerlo de cualquier manera razonable, pero no de una manera que sugiera que tiene el apoyo del licenciador o lo recibe por el uso que hace. 